\title{
Comparative in-vitro Evaluation of Dog Food Using Either Rice Gluten or Maize Fibre with Commercially Available Dog Food
}

\author{
Amardeep Kaur, APS Sethi and Udeybir Singh* \\ Department of Animal Nutrition, Guru Angad Dev Veterinary and Animal Sciences University, Ludhiana, INDIA \\ "Corresponding author: U Singh; E-mail: udeybirchahal@gmail.com
}

Received: 27 July, 2021

Revised: 03 Sept., 2021

Accepted: 11 Sept., 2021

\begin{abstract}
The study was carried out with an objective of studying in-vitro nutrient digestibility and quality evaluation of dog foods incorporated with $15 \%$ rice gluten and $2.5 \%$ maize fibre and its comparison with commercially available dog food for its nutritional worth and physical quality parameters. After standardization of diets, raw diets were subjected to different processing techniques viz. boiling and extrusion. Boiling of feed reduced the ether extract content of diets. The in-vitro analysis of dog feed involved two incubation phases: first, gastric digestion simulation at $39^{\circ} \mathrm{C}$ for $2 \mathrm{~h}$ in $\mathrm{HCl}$ solution in presence of pepsin and gastric lipase enzyme; second, small intestine digestion simulation at $39^{\circ} \mathrm{C}$ for $4 \mathrm{~h}$ using bile salts and pancreatin in phosphate buffer solution. Statistical analysis revealed that boiling of diet reduced the in-vitro digestibility of ether extract. Among different processing techniques, in-vitro digestibility was best in-case of extruded diets. In-vitro digestibility of CP had nonsignificant difference among different processing techniques; however CPD of boiled dog feed with $15 \%$ RG used dog feed was comparable with extruded and raw diet. Comparative evaluation of best preformed extruded feeds with commercial diets revealed that all diets had equal nutritional digestibility of various nutrients. $\mathrm{pH}, \mathrm{FFA}, \mathrm{PV}$ and aflatoxin content of feeds were within permissible limits. It was concluded that RG and MF can be included in dog diet at 15 and $2.5 \%$ level respectively showing equal digestibility of feed.
\end{abstract}

\section{HIGHLIGHTS}

( Processing such as extrusion significantly improved the in-vitro digestibility of various nutrients.

( In-vitro studies confirmed the non-significant differences among commercial and GADVASU prepared feeds.

Keywords: Boiling, Digestibility, Dog food, Extruded, In-vitro analysis, Raw diet

Increase in no. of nuclear families ensued by upsurge in pet adoption rate and increasing cognizance among pet owners about health of their pet and has boosted the growth of Indian pet food industry. Pet food manufacturers now emphasize more on introducing different specified pet food products that are rich in vitamins, mineral and other specific nutrients, thereby ensuring a high-quality food for pets. Home cooked pet food is nutritionally unbalanced and lack proper microbial evaluation which make pet prone to no. of pathological and metabolic diseases (Sethi et al., 2019). Tiwari et al. (2020) also observed that the consumption of milk is significantly $(\mathrm{P} \leq 0.05)$ higher in rural areas than urban areas. There are certain constraints in feeding commercially available dog food beside their high prices. Commercially available dog foods are formulated using wide variety of plant and animal based ingredients. The processing of commercial pet food can influence digestibility, nutrient bioavailability and safety. Digestibility of dog food is one of the imperative aspects for quality evaluation. Although much attention is paid to nutritional quality of $\mathrm{dog}$ food in the marketing of commercial food for dogs; there is limited literature on digestibility, keeping quality and aflatoxin content of

How to cite this article: Kaur, A., Sethi, A.P.S. and Singh, U. (2021) Comparative in-vitro Evaluation of Dog Food Using Either Rice Gluten or Maize Fibre with Commercially Available Dog Food. J. Anim. Res., 11(05): 885-890.

Source of Support: None; Conflict of Interest: None $\odot$ 
commercially available dog foods. In-vitro digestibility methods are comprehensively used as screening tools to apprise large number of ingredients, thus reducing the number of animals involved in in-vivo trials (de Godoy et al., 2016). For assessing the digestibility of commercially available diets for dogs, relatively simple, quick in-vitro protocol involving two incubation phases imitating gastric and small intestinal digestion was authenticated through in-vivo trials by Biagi et al. (2016). Keeping above points in mind, the present study was aimed (i) to study the invitro digestibility of dog feed containing $15 \% \mathrm{RG}$ and 2.5 MF (ii) its comparative evaluation with commercially available dog food.

\section{MATERIALS AND METHODS}

Diets were formulated for puppy stage of dogs according to the requirements prescribed by AAFCO (2014) containing $22.5 \%$ CP, $8.5 \%$ EE, $1.2 \%$ Calcium and $1 \%$ Phosphorus. Energy density of diet was kept $3500 \mathrm{kcal} \mathrm{ME} / \mathrm{kg}$ in accordance with Indian climatic conditions as described by ICAR (2013). The feeds were analyzed for proximate composition viz. dry matter (DM), crude protein (CP), ether extract (EE), total ash (TA), acid insoluble ash (AIA), crude fiber (CF) and phosphorus as per AOAC (2005) and calcium (Talapatra et al., 1940).

\section{Processing of feeds}

Raw, boiled and extruded diets were formulated in lab using dried ingredients. The formulated diets were analyzed for proximate composition.

\section{Raw dried diets}

Raw diets were formulated using dried ingredients which were kept overnight in hot air oven at $90^{\circ} \mathrm{C}$.

\section{Boiled Diets}

$100 \mathrm{~g}$ dried diets were boiled with $300 \mathrm{~mL}$ of water in pan for 15 minutes. Subsequently the boiled feed was transferred into trays to cool down and further kept overnight at $90^{\circ} \mathrm{C}$ in hot air oven for drying. After drying, the boiled feed was grinded and analyzed for proximate composition.

\section{Extruded Diets}

All ingredients were grinded in the mill and converted into the flour and were weighed as per the required level for formulation of complete dog feed and properly mixed in the mixer. The mixture was kept in vats. The die of desired product (bone shape) was fitted at the front portion of the extruder. The twin screw extruder and the main motor was switched on and the speed of the barrel was set to $35 \mathrm{~Hz}$. Heating temperature at Heater $1: 80^{\circ} \mathrm{C}$, Heater $2: 120^{\circ} \mathrm{C}$, Heater $3: 160^{\circ} \mathrm{C}$ respectively was set. After reaching at set barrel temperature, the barrel of the extruder was cleaned with hot water. The mixture of the formulated complete feed (powder form) was filled in the feeding chamber. The feeding machine was switched on and the speed was fixed at $15 \mathrm{~Hz}$. The ingredients mixture comes in the barrel and the finished product comes out of the machine. Now the cutter motor is switched on at the speed of $10 \mathrm{~Hz}$. Extruded dog feed was collected in large vessels. The product was cooled for about 30 minutes.

\section{In-vitro digestion}

In vitro method validated by Baigi et al. (2016) was used with some modifications.

\section{Sample preparation}

One day before weighed amount of samples were kept in hot air oven at $95^{\circ} \mathrm{C}$ until constant weight was obtained. After drying, sample was finely ground $(<1 \mathrm{~mm}$ particle size). Nylon bags were properly washed and kept in hot air oven at $65^{\circ} \mathrm{C}$ for collection of digested samples.

\section{Gastric digestion simulation}

$10 \mathrm{~g}$ of food samples was weighed and put in to the labeled $1 \mathrm{~L}$ bottles. Sample and $400 \mathrm{ml}$ of a pepsin- $\mathrm{HCl}$ solution ( $\mathrm{HCl} 0.075 \mathrm{~N}$; pepsin $2 \mathrm{~g} / \mathrm{L}$ ) containing gastric lipase (1 $\mathrm{g} / \mathrm{L})$ were incubated in a $1 \mathrm{~L}$ bottle in a bench top orbital shaking water bath at $39^{\circ} \mathrm{C}$ for $2 \mathrm{~h}$.

\section{Small intestine digestion simulation}

First, the $\mathrm{pH}$ of the above mixture was adjusted to 7.5 using $1 \mathrm{~N} \mathrm{NaOH}$. Bile salts (Cholic acid-Deoxycholic acid sodium salt mixture) were added to each bottle at a final 
concentration of $25 \mathrm{~g} / \mathrm{L}$. Then, $400 \mathrm{ml}$ of a pancreatin solution was added to each bottle. Finally, the bottles were placed in a bench top orbital shaking water bath at $39^{\circ} \mathrm{C}$ for $4 \mathrm{~h}$.

\section{Collection of the undigested fraction}

Nylon bags were first labeled and weighed empty after cooling. The undigested residue was filtered through nylon bags and washings were given with cold water and were tied securely. These tied nylon bags were kept in hot air oven at $65^{\circ} \mathrm{C}$ until constant weight. The dried weight of nylon bags was recorded and residue was analyzed for the determination of crude protein, ether extract and total ash as per AOAC (2005).

\section{Calculation and data analysis}

In order to determine the dry matter digestibility of the food samples residue obtained from each bottle after the in-vitro digestion was weighed and digestibility was calculated using following equation:

Dry matter digestibility $=(100-([$ residue weight $\times 100] /$

$$
\text { sample weight) }
$$

The undigested fraction was analyzed for crude protein, ether extract, and ash as per standard methods (AOAC, 2005). Nutrient digestibility was calculated with the following equation:

Nutrient digestibility $=100-\{[$ nutrient $\%$ in residue $\times(100$

- diet digestibility)] / nutrient $\%$ in $\operatorname{diet}$ \}

\section{RESULTS AND DISCUSSION}

Wet chemistry analysis of formulated control dog feed, feed with $15 \%$ rice gluten and $2.5 \%$ maize fibre supplementation level subjected to different processing techniques viz raw, boiling and extrusion is presented in table 1. Crude protein (CP), total ash (TA) and organic matter(OM) content of all formulated diets were within the desired levels. Ether extract (EE) content reduced $(\mathrm{P}<0.05)$ after boiling of diets. Hefnawy (2011) observed that lipid content reduced in pulses after cooking. It may be due to the diffusion of liquids into water. Crude fiber
(CF) content of diets remained unaltered $(\mathrm{P}<0.05)$ with processing except at $15 \% \mathrm{RG}$ level where it reduced $(\mathrm{P}<0.05)$ after boiling and extrusion. Nsa et al. (2014) asserted that $\mathrm{CF}$ content of un-decorticated castor oil seeds decreased after boiling. This may be due to softening of fiber fraction during boiling. Calcium $(\mathrm{Ca})$ and phosphorus (P) level in all the extruded diets were similar. Commercial diet contained $25 \% \mathrm{CP}, 6.8 \% \mathrm{EE}, 4.1 \% \mathrm{CF}, 7.25 \% \mathrm{TA}$, $1.59 \mathrm{Ca}$ and $0.61 \% \mathrm{P}$.

In-vitro nutrient digestibility of control feed, feed containing RG $15 \%$ and $2.5 \%$ MF subjected to different processing techniques is depicted in table 2 . Dry matter digestibility (DMD) of control boiled diet was significantly $(\mathrm{P} \leq 0.05)$, higher than raw diet but lower $(\mathrm{P}<0.05)$ than extruded dog feed. Non-significant $(\mathrm{P}<0.05)$ difference was observed in DMD of raw and boiled feeds when $15 \% \mathrm{RG}$ and $2.5 \% \mathrm{MF}$ was included in dog feed. However, DMD was highest in case of all extruded dog feeds ( $0,15 \% \mathrm{RG}$ and $2.5 \% \mathrm{MF})$. Inal et al. (2017) testified highest dry matter digestibility in case of extruded food. Non-significant difference was discerned in crude protein digestibility (CPD) of diets among different processing techniques with control and $2.5 \%$ MF containing feed; however, at $15 \% \mathrm{RG}$ inclusion level, CPD of boiled dog food was comparable with raw and extruded dog food. Lankhorst et al. 2007 observed that in-vitro protein digestibility (IVPD) was not affected by different extrusion conditions on other hand El-Adawy (2002) stated that IVPD for unprocessed chickpea (Cicer arietinum L.) increased from $83.61 \%$ to $88.52 \%$ after cooking for $90 \mathrm{~min}$. Singh et al. (2020) also reported that extrusion significantly $(\mathrm{P}<0.01)$ increased the dry matter (DMD) and organic matter digestibility (OMD) in diets. DMD and OMD was lowest in-case of raw diets which improved after boiling and further improved after extrusion of diets. However, Overland et al. (2007) reported that the crude protein digestibility in cat and dog foods was not affected by the extrusion. In another study conducted by Kaur et al. (2021) also concluded that extrusion has remarkable $(\mathrm{P}<0.05)$ effect on the nutrient digestibility of different diets prepared by using dal churi at various levels.

Ether digestibility decreased after boiling of dog feed but there were non-significant difference in EED of raw and extruded diets at all levels. Cipollini (2008) studied that EE digestibility of dry dog food was higher than wet dog food (94.9 vs. 87.7\%). 
Table 1: Chemical composition of formulated dog food

\begin{tabular}{|c|c|c|c|c|c|c|c|c|c|c|c|c|}
\hline \multirow{2}{*}{$\begin{array}{l}\text { Parameters } \\
\%\end{array}$} & \multicolumn{4}{|c|}{ Control feed } & \multicolumn{4}{|c|}{ Rice gluten $15 \%$} & \multicolumn{4}{|c|}{ Maize fibre $2.5 \%$} \\
\hline & Raw & Boiled & Extruded & P-value & Raw & Boiled & Extruded & P-value & Raw & Boiled & Extruded & P-value \\
\hline $\mathrm{CP}$ & 23.18 & 22.75 & 23.18 & 0.650 & 22.75 & 22.84 & 22.75 & 0.465 & 23.18 & 22.75 & 23 & 0.697 \\
\hline $\mathrm{EE}$ & $7.42^{\mathrm{c}}$ & $3.38^{\mathrm{a}}$ & $6.1^{\mathrm{b}}$ & 0.002 & $9.6^{\mathrm{c}}$ & $4.3^{\mathrm{a}}$ & $8.24^{\mathrm{b}}$ & 0.000 & $8.4^{\mathrm{b}}$ & $4.78^{\mathrm{a}}$ & $7.65^{\mathrm{b}}$ & 0.001 \\
\hline $\mathrm{CF}$ & 3.8 & 3.5 & 3.7 & 0.529 & $4.8^{\mathrm{b}}$ & $4.2^{\mathrm{a}}$ & $4.3^{\mathrm{a}}$ & 0.021 & 5 & 4.5 & 4.1 & 0.324 \\
\hline Total Ash & 7.6 & 7.56 & 7.32 & 0.270 & 6.6 & 6.2 & 6.37 & 0.185 & 7.69 & 6.7 & 7.34 & 0.213 \\
\hline $\mathrm{OM}$ & 92.4 & 92.44 & 92.68 & 0.262 & 93.4 & 93.8 & 93.63 & 0.185 & 92.31 & 93.3 & 92.66 & 0.213 \\
\hline
\end{tabular}

Means with different superscript differ significantly.

Table 2: In-vitro nutrient digestibility of control feed, feed containing RG $15 \%$ and $2.5 \mathrm{MF}$ subjected to different processing techniques

\begin{tabular}{|c|c|c|c|c|c|c|c|c|c|c|c|c|}
\hline \multirow{3}{*}{$\begin{array}{l}\text { Nutrient } \\
\text { digestibility } \\
\% \\
\end{array}$} & \multicolumn{12}{|c|}{ Diets } \\
\hline & \multicolumn{4}{|c|}{ Control feed } & \multicolumn{4}{|c|}{ Rice gluten $15 \%$} & \multicolumn{4}{|c|}{ Maize fibre $2.5 \%$} \\
\hline & Raw & Boiled & Extruded & P-value & Raw & Boiled & Extruded & P-value & Raw & Boiled & Extruded & P-value \\
\hline $\mathrm{DM}$ & $80.46^{\mathrm{a}}$ & $84.01^{\mathrm{b}}$ & $92.2^{\mathrm{c}}$ & 0.001 & $84.76^{\mathrm{a}}$ & $86.82^{\mathrm{a}}$ & $92.7^{\mathrm{b}}$ & 0.004 & $81.90^{\mathrm{a}}$ & $83.98^{\mathrm{a}}$ & $91.42^{b}$ & 0.003 \\
\hline $\mathrm{CP}$ & 90.16 & 91.59 & 92.80 & 0.145 & $91.25^{\mathrm{a}}$ & $91.89^{\mathrm{ab}}$ & $92.6^{\mathrm{b}}$ & 0.064 & 90.01 & 91.02 & 91.87 & 0.150 \\
\hline $\mathrm{EE}$ & $94.18^{b}$ & $83.34^{\mathrm{a}}$ & $94.92^{b}$ & 0.032 & $95.52^{\mathrm{b}}$ & $75.88^{\mathrm{a}}$ & $94.92^{\mathrm{b}}$ & 0.000 & $96.2^{\mathrm{b}}$ & $76.89^{a}$ & $94.4^{\mathrm{b}}$ & 0.000 \\
\hline $\mathrm{OM}$ & $84.38^{\mathrm{a}}$ & $86.68^{\mathrm{b}}$ & $91.27^{\mathrm{c}}$ & 0.002 & $86.51^{\mathrm{a}}$ & $88.76^{\mathrm{b}}$ & $93.2^{\mathrm{c}}$ & 0.002 & $83.22^{\mathrm{a}}$ & $84.14^{\mathrm{a}}$ & $92.3^{\mathrm{b}}$ & 0.004 \\
\hline
\end{tabular}

Means with different superscript differ significantly.

Table 3: In-vitro digestibility of commercial feed and its Comparative evaluation with control, $15 \%$ RG and $2.5 \%$ MF containing feeds

\begin{tabular}{lllllll}
\hline $\begin{array}{l}\text { Digestibility of Parameters } \\
\text { \% }\end{array}$ & Commercial feed & Control group & MF 2.5\% & RG 15\% & PSE & P-value \\
\hline DM & 91.80 & 92.20 & 91.42 & 92.70 & 0.274 & 0.477 \\
CP & 92.46 & 92.80 & 91.87 & 92.60 & 0.211 & 0.674 \\
EE & 93.69 & 94.92 & 94.40 & 94.92 & 0.315 & 0.568 \\
OM & 90.40 & 91.27 & 92.30 & 93.20 & 0.446 & 0.070 \\
\hline
\end{tabular}

In dog foods, with 0 and $15 \% \mathrm{RG}$, organic matter digestibility (OMD) was highest $(\mathrm{P}<0.01)$ in case of extruded diets and lowest in case of raw diets. Diet with $2.5 \% \mathrm{MF}$, non-significant difference was recorded in OMD of raw and boiled dog food. Extrusion of dog food proved significant improvement in the digestibility of nutrients.

Formulated extruded feeds were compared with commercially available feed (table 3). Data analysis revealed that there was non-significant difference with respect to nutrient digestibility (DMD, CPD, EED and OMD) between commercially available feed and formulated feeds.
Physico-chemical properties and aflatoxin content of formulated $\operatorname{dog}$ feeds and commercial dog feed are depicted in table 4. Among the formulated and commercial feeds analyzed it was observed, commercial feed was highly acidic, followed by feed with 15\% RG, 2.5\% MF and without RG or MF inclusion. Free fatty acid (FFA) content of formulated feeds was lowest where $2.5 \% \mathrm{MF}$ was added and highest in feed with $15 \%$ RG. FFA content in all feeds was within the permissible limits. Pearson (1968) reported that minced beef had FFA content in the range of 0.38 to $1.74 \%$ and had a maximum acceptability limit of $1.8 \%$ FFA in view of their progressive increase during storage. 
Table 4: Physico-chemical properties and aflatoxin content of formulated feeds and commercial feed

\begin{tabular}{lllll}
\hline Feeds & $\mathbf{p H}$ & FFA(\% oleic acid) & PV (mEq/kg) & Aflatoxin (ppb) \\
\hline Commercial feed & 4.87 & 0.3948 & 8 & 7.5 \\
Control group & 5.34 & 0.536 & 10 & 5.7 \\
Maize fibre 2.5\% feed & 5.14 & 0.3384 & 8 & 9.1 \\
Rice gluten 15\% feed & 4.98 & 1.1280 & 6 & 10 \\
\hline
\end{tabular}

Maximum per oxide value (PV) was observed where $0 \%$ $\mathrm{RG}$ or MF was added other feeds. However, it was closely followed by $2.5 \% \mathrm{MF}$ and $15 \% \mathrm{RG}$ supplemented diets. Osawa et al. (2008) reported the value of FFA and PV of pet food in the range of $4.6 \pm 0.1$ to $28.0 \pm 0.6 \%$ oleic acid and $1.4 \pm 0.1$ to $6.8 \pm 0.3 \mathrm{meq}_{2} / \mathrm{kg}$ respectively. Aflatoxin content in all the feeds formulated and commercial feed was with-in desired limits. According to FDA (2019), maximum permissible limit for Aflatoxin in complete pet food of all ages should not be more than $20 \mathrm{ppb}$.

\section{CONCLUSION}

The in-vitro studies conclusively indicated that extrusion improves the digestibility of nutrients and there was nosignificant difference $(\mathrm{P} \leq 0.05)$ between overall nutrient digestibility of commercially available dog feed and GADVASU prepared extruded dog feeds. Thus RG and MF can be incorporated in dog feed at 15 and 2.5\% level, respectively.

\section{ACKNOWLEDGEMENTS}

This study was conducted as part of DBT-GADVASU Canine Research Centre and Network vide order no.BT/ ADV/Canine Health/GADVASU/2017-2018 under the sub-head entitled "Nutritional and processing interventions for developing pet foods" under the ageis of Department of Biotechnology, Ministry of Science \& Technology, Govt. of India. Authors are thankful to Govt. of India, Department of Biotechnology for giving us such opportunity.

\section{REFERENCES}

AOAC, 2005. Official Methods of Analysis, $18^{\text {th }}$ Edition. Association of Official Analytical Chemists, Washington, DC.

AAFCO, 2015. Official Publication. Champaign, IL: Association of American Feed Control Officials.
Biagi, G., Cipollini, I., Grandi, M., Pinna, C., Vecchiato, C.G. and Zaghini, G. 2016. A new in vitro method to evaluate digestibility of commercial diets for dogs. Ital. J. Anim. Sci., 15(4): 617-25.

Cipollini, I. 2008. Pet food: quality and quality improvement. Esame Finale Anno.

De-Godoy, M.R.C., Hervera, M., Swanson, K.S. and Fahey, G.C. 2016. Innovations in canine and feline nutrition: technologies for food and nutrition assessment. Annu. Rev. Anim. Biosci., 4(1): 311-33.

El-Adawy, T.A. 2002. Nutritional composition and antinutritional factors of chickpeas (Cicer arietinum L.) undergoing different cooking methods and germination. Plant Foods Hum. Nutr., 57(1): 83-97.

Food and Drug Administration. 2019. Sec. 683.100 Action Levels for Aflatoxins in Animal Food. (https://www.fda.gov/ICECI/ ComplianceManuals/CompliancePolicyGuidanceMan ual/de fault.htm)

Hullar, I., Fekete, S. and Szocs, Z. 1998. Effect of extrusion on the quality of soybean-based cat food. J. Anim. Physiol. Anim. Nutr., 80(1-5): 201-06.

Hefnawy, T.H. 2011. Effect of processing methods on nutrient composition and anti-nutritional factors in lentsils (Lens culinaris). Ann. Agric. Sci., 56(2): 57-61.

ICAR. 2013. Nutrient Requirements of Animals - Companion, Laboratory and Captive Wild Animals (ICAR-NIANP).

Inal, F., Alatas, M.S., Kahraman, O., Inal, S., Uludag, M., Gurbuz, E. and Polat, E.S. 2018. Using of pelleted and extruded foods in dog feeding. Kafkas Univ. Vet. Fak. Derg., 24(1): 131-36.

Kaur, M., Singh, U., Sethi, A.P.S., Kaur, H. and Malavi, O.P. 2021. Nutritional assessment of dal churi in dog food. Haryana Vet., 60(1): 119-22.

Lankhorst, C., Tran, Q.D., Havenaar, R., Hendriks, W.H. and Van der, Poela, A.F.B. 2007. The effect of extrusion on the nutritional value of canine diets as assessed by in-vitro indicators. Anim. Feed Sci. Technol., 138(3-4): 285-97.

Nsa, E.E., Ukachukwu, S.N., Isika, M.A. and Ozung, P.O. 2011. Effect of boiling and soaking durations on the proximate composition, ricin and mineral contents of undeorticated 
Castor oil seeds (Ricinus communis). Int. J. Plant Anim. Env. Sci., 1(3): 244-52.

Osawa, C.C., Goncalves, L.A.G. and Ragazzi, S. 2008. Evaluation of the quality of pet foods using fast techniques and official methods. Cienc. Tecnol. Aliment. Campinas., 28(Supl.): 223-30.

Overland, M., Romarheim, O.H., Ahlstrøm, O., Storebakken, T. and Skrede, A. 2007. Technical quality of dog food and salmon feed containing different bacterial protein sources and processed by different extrusion conditions. Anim. Feed Sci. Technol., 134(1-2): 124- 37

Pearson, D. 1968. Application of chemical methods for assessment of beef quality. II method related to protein break down. J. Sci. Food Agric., 19(7): 366-69.

Sethi, A.P.S., Kaur, A. and Singh, U. 2019. Prospects and research priorities in canine nutrition. In: lead paper presented at International conference on animal nutrition (INCAN 2019). Nutritional strategies for improving farm profitability and clean animal productionll. XVIII Biennial conference, Kolkata, West Bengal.
Singh, C., Sethi, A.P.S., Singh, U., Malav, O.P. and Kaur, H. 2020. Effect of Tomato Pomace supplementation on the nutritional value of $\operatorname{dog}$ diets as assessed by in-vitro digestibility. $J$. Anim. Res., 10(6): 925-30.

Talapatra, S.K., Ray, S.C. and Sen, K.C. 1940. The analysis of minerals constituents in biological materials. Ind. J. Vet. Sci. Anim. Husbandry, 10: 243-47.

Tiwari, A., Sethi, A.P.S., Singh, U. and Mavi, G. 2020. Appraisal of Feeding Practices Followed by Dog Owners in Ferozepur and Fazilka Districts. J. Anim. Res., 10(5): 01-05. 